\title{
Alogliptin: a new addition to the class of DPP-4 inhibitors
}

This article was published in the following Dove Press journal: Diabetes, Metabolic Syndrome and Obesity:Targets and Therapy 16 July 2009

Number of times this article has been viewed

\author{
Radha Andukuri \\ Andjela Drincic \\ Marc Rendell \\ Division of Endocrinology, \\ Department of Medicine, Creighton \\ University School of Medicine, \\ Omaha, Nebraska, USA
}

Correspondence: Marc Rendell Creighton Diabetes Center, 60I North 30th Street, Omaha, NE 68I3I, USA Fax + I 402-280-5655 Email Rendell@asndi.com
Background: Alogliptin is an oral antihyperglycemic agent that is a selective inhibitor of the enzyme dipeptidyl peptidase-4 (DPP-4). Inhibition of DPP-4 elevates levels of the incretin hormones glucagon-like peptide (GLP-1) and glucose-dependent insulinotropic polypeptide (GIP) by preventing their degradation.

Objective: To review the evolution of alogliptin and its pharmacokinetics, pharmacodynamics, clinical efficacy and adverse effects. In addition, we compared alogliptin to other DPP-4 inhibitors.

Methods: A comprehensive literature search was performed using the term 'alogliptin'. Original research articles and review articles as well as scientific abstracts were included.

Results: Alogliptin raises postprandial levels of GLP-1. It has excellent bioavailability exhibiting a median $\mathrm{T}_{\max }$ ranging from 1 to 2 hours and a mean half-life of 12.4 to 21.4 hours across all doses. When given as monotherapy, mean hemoglobin $\mathrm{A}_{1 \mathrm{c}}\left(\mathrm{HbA}_{1 \mathrm{c}}\right)$ reductions achieved were $0.5 \%$ to $0.6 \%$. Combination therapy yielded similar reductions $(-0.5 \%$ with metformin, $-0.6 \%$ with glyburide, $-0.8 \%$ with pioglitazone and $-0.6 \%$ with insulin). Administration of alogliptin does not promote weight loss but has not resulted in weight gain. The agent is relatively well tolerated with few adverse effects, the major finding being a marginally higher rate of skin events, primarily pruritus.

Conclusions: Alogliptin causes significant reductions in $\mathrm{HbA}_{1 \mathrm{c}}$ when used alone or in combination with other oral agents in patients with type 2 diabetes similar to other DPP-4 inhibitors in current clinical use. The side effect profile also does not differ from that of other DPP-4 inhibitors. However, long-term studies are necessary before the place of alogliptin in the management of type 2 diabetes can be established.

Keywords: alogliptin, DPP-4 inhibitors, GLP-1, vildagliptin, sitagliptin, saxagliptin

\section{Introduction}

Type 2 diabetes mellitus is a disorder of blood glucose control owing to multiple metabolic abnormalities, including insufficient insulin secretion, impaired response of liver and peripheral tissues to insulin (insulin resistance), progressive loss of betacell function, disregulation of glucagon secretion and disturbed incretin hormone physiology. ${ }^{1}$ The prevalence of diabetes is increasing worldwide from estimated $2.8 \%$ in 2000 to $4.4 \%$ in $2030 .^{2}$ The total number of people with diabetes is projected to rise from 171 million in 2000 to 366 million in $2030 .{ }^{2}$ While tight control of diabetes substantially decreases the risk of microvascular complications, ${ }^{3}$ only $37 \%$ of patients currently reach the target hemoglobin $\mathrm{A}_{1 \mathrm{c}}\left(\mathrm{HbA}_{1 \mathrm{c}}\right)$ of $<7 \%$, goal set by the American Diabetes Association. ${ }^{4}$ The choice of agents to improve blood glucose 
levels includes metformin, sulfonylureas, disaccharidase inhibitors, thiazolidinediones and insulin. Two new classes of agents which target the incretin system have recently come into clinical use. These are the GLP - 1 receptor agonists and dipeptidyl peptidase-4 (DPP-4) inhibitors.

\section{The incretin system}

Incretins are hormones secreted by the gut in response to oral nutrient intake. Incretin secretion results in an augmentation of insulin secretion over and above the response solely attributable to the rise in intravenous glucose concentration. Two incretin hormones are of particular interest: glucagon-like polypeptide (GLP-1) and glucose-dependent insulinotropic peptide, also known as gastric inhibitory polypeptide (GIP). GIP and GLP-1 are both secreted within minutes of food consumption and act through distinct receptors. ${ }^{5,6,7}$ Both peptides act on pancreatic beta-cells to stimulate glucose-dependent insulin secretion, induction of beta-cell proliferation, and enhance resistance to apoptosis. Both GIP and GLP-1 are rapidly degraded by the enzyme DPP-4.

GIP is the first incretin to be discovered. ${ }^{8}$ It is secreted proximally from the $\mathrm{K}$ cells of the gut in response to oral ingestion of food containing glucose and fat. GIP promotes a glucose-dependent insulin secretion. GIP also promotes energy storage by adipocytes and enhances bone formation via stimulation of osteoblast proliferation and inhibition of apoptosis. ${ }^{6}$ Effects of GIP include incorporation of fatty acids into triglycerides, stimulation of lipoprotein lipase activity, modulation of fatty acid synthesis ${ }^{8}$ and promotion of beta-cell proliferation and survival. ${ }^{9,10}$ Plasma concentrations of GIP are reported to be normal or increased in diabetes, ${ }^{11,12}$ but the insulinotropic effect is deficient. This is thought to be due to downregulation of GIP expression/activity. ${ }^{13,14}$

GLP-1 is a 30/31 amino acid peptide secreted from the $\mathrm{L}$ cells of the distal gut into the capillaries and then into the blood stream. It is quickly metabolized by DPP-4 giving active GLP-1 a half-life of only 1 to 2 minutes. Despite its short life, GLP-1 reaches the pancreatic beta-cell causing a glucose-dependent increase in insulin secretion. Other effects of GLP-1 include suppression of glucagon secretion, slowing of gastric emptying time and promotion of satiety. ${ }^{15}$ GLP-1 also promotes differentiation and proliferation of beta-cells and inhibition of apoptosis, thus offering the potential to reverse the effects of diabetes on beta-cell mass. GLP-1, but not GIP, controls glycemia via additional actions on inhibition of gastric emptying, food intake and glucagon secretion. ${ }^{7}$ Postprandial GLP-1 release is about $25 \%$ to $30 \%$ lower in patients with type 2 diabetes and those with impaired glucose tolerance. ${ }^{16}$ In addition, the insulinotropic effect of GLP-1 is blunted in diabetes, ${ }^{17,18}$ perhaps in part related to glucagon levels. ${ }^{19,20}$ GLP-1 infusions have shown more promising results than those of GIP in lowering plasma glucose in diabetes. ${ }^{21,22}$ GLP-1 also promotes satiety, and sustained GLP-1-receptor activation is associated with weight loss in both preclinical and clinical studies.

Incretin pathway effects can be enhanced in two ways: by administering GLP-1 agonists, or by slowing their degradation with DPP-4 inhibitors. Several studies have now shown that GLP-1 can lower glucose levels even in patients with severe beta-cell impairment, presumably as a result of lowered glucagon levels and other non insulin related effects. ${ }^{23}$ Subcutaneous infusion of GLP-1 resulted in lower overall glycemic levels than pioglitazone treatment, and the effect was additive. ${ }^{24}$ Treatment with the long acting GLP-1 derivative liraglutide significantly reduced overall 24-hour glucose levels as well as those of glucagons. ${ }^{25}$ Continuous subcutaneous infusion of GLP-1 for 3 months lowered capillary blood glucose levels in elderly type 2 diabetic subjects. ${ }^{26}$ The glycemic effects of GLP-1 are associated with improvement in endothelial function. ${ }^{27}$

Exendin is a reptilian peptide with affinity for the mammalian GLP-1 receptor and relative resistance to degradation, resulting in a relatively long-lasting effect. ${ }^{28}$ Exenatide treatment has shown promising effects either as monotherapy ${ }^{29}$ or in combination with other agents. ${ }^{30-32}$ Treatment with exendin-4 has reduced postprandial hyperglycemia in Type I diabetes, confirming that the mechanism of action does not rely solely on insulin secretion. ${ }^{33}$ In 272 metformin treated patients with initial $\mathrm{HbA}_{1 \mathrm{c}}$ of $8.2 \pm 1.1 \%$, $\mathrm{HbA}_{1 \mathrm{c}}$ levels dropped by $0.8 \pm 0.1 \%$ and weight decreased by $2.8 \pm 0.5 \mathrm{~kg}$ after 30 weeks of treatment with $10 \mu \mathrm{g}$ of exenatide. ${ }^{31}$ In 377 sulfonylurea treated subjects with initial $\mathrm{HbA}_{1 \mathrm{c}}$ of $8.6 \pm 1.2 \%$ given exenatide $10 \mu \mathrm{g}$ twice daily, $\mathrm{HbA}_{1 \mathrm{c}}$ dropped $-0.9 \pm 0.1 \%$ and weight was reduced $-1.6 \pm 0.3 \mathrm{~kg}$ from baseline $\left(P<0.05\right.$ vs placebo). ${ }^{32}$ Exenatide is injectable and needs to be taken twice daily. There are considerable gastrointestinal side effects in up to $40 \%$ of patients.

An alternative to supplementation of GLP-1 is to inhibit the rapid degradation of this hormone by DPP-4. ${ }^{33,34}$ Several DDP-4 inhibitors have been developed and have come into clinical use. ${ }^{35,36}$ Currently, sitagliptin is the only DPP-4 inhibitor available in the United States. ${ }^{37}$ Sitagliptin is effective as monotherapy ${ }^{38,39}$ and in combination with metformin. ${ }^{40-42}$ Sitagliptin is generally well tolerated with an overall incidence of adverse experiences comparable to 
placebo, a low risk of hypoglycemia and gastrointestinal problems, and a neutral effect on body weight. ${ }^{43}$

Vildagliptin is approved in Europe and in Latin America ${ }^{44}$ It is efficacious as monotherapy ${ }^{45}$ and in combination with metformin. ${ }^{46}$ In a comparison study of vildagliptin vs metformin in drug-naïve patients with type 2 diabetes, metformin treatment resulted in greater weight loss and a superior glucose-lowering effect, but had a higher incidence of gastrointestinal side effects. ${ }^{47}$ Vildagliptin added to metformin therapy provides a modest reduction in $\mathrm{HbA}_{1 c}$ comparable to that of glimepiride but without the significant weight gain and hypoglycemia which occurs with the sulfonylureas. ${ }^{48}$ Inhibition of GLP-1 and GIP by DPP-4 inhibitors such as vildagliptin and sitagliptin result in significant improvements in glucose levels in patients with type 2 diabetes. The glucose-lowering effect of currently available DPP-4 inhibitors appears to be somewhat less than those of exenatide and, unlike exenatide, there is no beneficial weight loss. ${ }^{49,50}$

Recently a new DPP-4 inhibitor alogliptin has been developed. It is our purpose to review the properties of alogliptin and its potential benefits in treating diabetes.

\section{Pharmacokinetics and pharmacodynamics of alogliptin}

Alogliptin benzoate is an orally available quinazolinonebased noncovalent inhibitor of DPP $4 .{ }^{49}$ It is a highly potent, highly selective, orally available DPP-4 inhibitor. Its selectivity for DPP-4 is $>10,000$-fold greater than that of the other DPP isozymes $2 / 8 / 9.51,52$

\section{Metabolism}

Disposition of alogliptin was studied in eight healthy volunteers given a dose of $25 \mathrm{mg} .{ }^{53} \mathrm{It}$ is rapidly absorbed as early as 15 minutes with a $\mathrm{T}_{\max }$ of 2 hours. The mean volume of distribution of alogliptin was $60.9 \mathrm{~L}$, greater than that of body water $(42 \mathrm{~L})$, indicating that it is well distributed in all tissues. Approximately $85 \%$ of plasma radioactivity, $95 \%$ of urine radioactivity and $88 \%$ of fecal radioactivity was accounted for by the parent compound suggesting minimal metabolism..$^{53}$ It is metabolized to two minor metabolites. $\mathrm{M}-1$, an N-demethylated metabolite and M-2, an N-acetylated metabolite. M- 1 an M- 2 are formed and represent $<2 \%$ and $6 \%$ respectively, of parent drug concentrations in plasma and urine.

The pharmacokinetic and pharmacodynamic profiles of alogliptin in healthy subjects were evaluated with single doses of $6.25 \mathrm{mg}, 12.5 \mathrm{mg}, 25 \mathrm{mg}, 50 \mathrm{mg}, 100 \mathrm{mg}, 200 \mathrm{mg}$,
$400 \mathrm{mg}$, and $800 \mathrm{mg} .{ }^{54}$ Multiple-dose studies were done in subjects with type 2 diabetes and doses of $25 \mathrm{mg}, 100 \mathrm{mg}$ and $400 \mathrm{mg}$ were given for 14 days. ${ }^{55}$ Alogliptin is rapidly absorbed after oral administration with median $\mathrm{T}_{\text {max }}$ ranging from 1 to 2 hours across all doses. Mean half-life was 12.4 to 21.4 hours across all doses. ${ }^{54}$

\section{DPP-4 inhibition}

DPP-4 enzyme activity and active GLP-1 levels were measured in human studies after single and multiple doses of alogliptin. ${ }^{54,55}$ Mean plasma DPP-4 inhibition after a single dose of alogliptin (25 mg to $800 \mathrm{mg}$ ) ranged from $74.3 \%$ to $94 \%$ at 24 hours and $47.5 \%$ to $83 \%$ at 72 hours. ${ }^{54}$ After 14 days of dosing ( $25 \mathrm{mg}$ to $400 \mathrm{mg}$ ), mean peak DPP-4 inhibition ranged from $94 \%$ to $99 \%$ and mean inhibition at 24 hours after dosing ranged from $82 \%$ to $97 \%$ across all doses. Plasma DPP- 4 activity was inhibited by $>80 \%$ after 24 hours, supporting a once daily regimen. ${ }^{55}$ An increase of 2- to 4-fold in active GLP-1 levels in response to alogliptin occurs and is most evident after meals. ${ }^{55}$ This is similar to GLP-1 values observed with sitagliptin treatment. ${ }^{37}$

\section{Excretion}

Alogliptin is primarily excreted unchanged in the urine accounting for $\sim 60 \%$ to $71 \%$ of the administered dose. Mean clearance (165 to $254 \mathrm{~mL} / \mathrm{min}$ ) across doses slightly exceeded the GFR (glomerular filtration rate) suggesting some renal secretion..$^{53}$ The fact that it is excreted unchanged through the kidney raises concern for possible interaction with other renally excreted drugs like metformin. However, a multiple-dose drug interaction study done with alogliptin and metformin found no pharmacokinetic interaction. ${ }^{56}$

\section{Drug interaction studies}

In addition to metformin, drug interaction studies were done with other common antidiabetic agents ( glyburide, ${ }^{57}$ and pioglitazone. ${ }^{58}$ Studies with CYP inhibitors disclosed no significant interactions with fluconazole, ketoconazole and gemfibrozil. ${ }^{59}$ Other interaction studies with warfarin, ${ }^{60}$ cyclosporine, ${ }^{61}$ ethinylestradiol and norethindrone, ${ }^{62}$ atorvastatin, ${ }^{63}$ and digoxin ${ }^{64}$ were also reassuring.

\section{Efficacy}

\section{Alogliptin monotherapy}

Alogliptin has been studied as both monotherapy and in combination with other oral agents in type 2 diabetes patients with $\mathrm{HbA}_{1 \mathrm{c}}$ between $7 \%$ and $10 \%$. DeFronzo et al evaluated alogliptin as monotherapy for treatment-naïve patients 
with type $2 \mathrm{DM}$ for 26 weeks. ${ }^{65}$ Mean $\mathrm{HbA}_{1} \mathrm{c}$ decreased significantly with $12.5 \mathrm{mg}(-0.56 \%)$ and $25 \mathrm{mg}(-0.59 \%)$ compared with placebo $(-0.02 \%)$. Fasting plasma glucose improved within a week and $\mathrm{HbA}_{1} \mathrm{c}$ within 4 weeks. Differences in fasting plasma glucose from placebo at week 26 were significant at $-22 \mathrm{mg} / \mathrm{dL}$ and $-28 \mathrm{mg} / \mathrm{dL}$ with $12.5 \mathrm{mg}$ and $25 \mathrm{mg}$ respectively. ${ }^{65}$

\section{Sulfonylurea add-on}

Pratley et al evaluated combination therapy of alogliptin added to glyburide (mean dose was 11.2 to $12.4 \mathrm{mg}$ ) and showed significant $\mathrm{HbA}_{1 \mathrm{c}}$ reductions across increasing doses of alogliptin: $-0.39 \%$ with $12.5 \mathrm{mg}$, and $-0.53 \%$ with $25 \mathrm{mg}$ compared with placebo $(+0.01 \%) .{ }^{66}$ Reductions were seen as early as 4 weeks and continued throughout the 26-week period. More patients in the alogliptin group achieved $\mathrm{HbA}_{1 \mathrm{c}}$ reductions of $>0.5 \%$ (26.3\% with placebo, $47.3 \%$ with $12.5 \mathrm{mg}$ and $50.5 \%$ with $25 \mathrm{mg}$ of alogliptin; $P<0.001$ ). Similarly more patients in the alogliptin arm had $\mathrm{HbA}_{1 \mathrm{c}}$ reductions of $>1 \%$ compared with placebo (13.1\% with placebo, $18.7 \%$ with $12.5 \mathrm{mg}$ and $29.8 \%$ with $25 \mathrm{mg}$ of alogliptin; $P<0.001$ for $25 \mathrm{mg}$ and 0.149 for $12.5 \mathrm{mg}$ ). The improvement was noted primarily in postprandial glucose since the mean change in fasting plasma glucose was small and non significant across all groups. ${ }^{66}$

\section{Metformin add-on}

Nauck et al assessed the efficacy of alogliptin as an add-on to metformin therapy for 26 weeks. ${ }^{67}$ Mean HbA1c reductions noted with placebo, alogliptin $12.5 \mathrm{mg}$ and $25 \mathrm{mg}$ were $-0.1 \%,-0.6 \%$ and $-0.6 \%$ respectively $(P>0.001)$. Reductions in fasting plasma glucose were observed at all metformin doses and were significant in patients receiving either dose of alogliptin compared with placebo: $0 \mathrm{mg} / \mathrm{dL}$, $-19 \mathrm{mg} / \mathrm{dL}$ and $-17 \mathrm{mg} / \mathrm{dL}$ with placebo, alogliptin $12.5 \mathrm{mg}$ and $25 \mathrm{mg}$ respectively. ${ }^{67}$

\section{Pioglitazone (TZD) add-on}

Alogliptin was utilized as add-on therapy for patients on thiazolidinediones (pioglitazone) with or without metformin and sulfonylurea and followed for 26 weeks. ${ }^{68}$ Reductions in $\mathrm{HbA}_{1 \mathrm{c}}$ were: $-0.19 \%,-0.66 \%$ and $-0.80 \%$ for placebo, $12.5 \mathrm{mg}$ and $25 \mathrm{mg}$ of alogliptin respectively $(P<0.001)$. Meaningful reductions were seen regardless of the dose of pioglitazone and with or without sulfonylurea or metformin. Mean differences in fasting plasma glucose from placebo were $-14 \mathrm{mg} / \mathrm{dL}$ with both $12.5 \mathrm{mg}$ and $25 \mathrm{mg}$ $(P<0.001){ }^{68}$

\section{Insulin add-on}

In a double-blind placebo-controlled study, 390 subjects on insulin with or without metformin were randomized to receive alogliptin at $12.5 \mathrm{mg}$ or $25 \mathrm{mg}$ and followed for 26 weeks. ${ }^{69}$ Subjects on very high insulin doses ( $>100$ units /day) and $\mathrm{HbA}_{1 \mathrm{c}}<8 \%$ were excluded. The mean dose of insulin was 56.5 units/day and mean $\mathrm{HbA}_{1 \mathrm{c}}$ was $>9 \%$ at the entry. The addition of alogliptin resulted in $\mathrm{HbA}_{1 \mathrm{c}}$ reduction of $-0.51 \%$ and $-0.59 \%$ and was significant $(P<0.001$ for both doses. Reductions were seen regardless of the insulin dose and whether or not they were on metformin. Mean FPG reductions from placebo were $-4 \mathrm{mg} / \mathrm{dL}$ and $-18 \mathrm{mg} / \mathrm{dL}$ for $12.5 \mathrm{mg}$ and $25 \mathrm{mg}$ respectively. ${ }^{69}$

\section{Effects on pancreatic beta-cell function}

In the 26-week randomized double-blind placebo-controlled study done by DeFronzo with alogliptin, modest apparent increases in proinsulin:insulin ratio and beta-cell function determined by homeostasis model assessment (HOMA- $\beta$ ) did not achieve statistical significance. ${ }^{65}$ Similar results were observed by Pratley et al evaluating efficacy of alogliptin with glyburide. Improvements in measurement of beta-cell function (as measured by fasting insulin concentration, proinsulin to insulin ratio and HOMA- $\beta$ ) were not clinically significant ( $P \geq 0.124$ ) (66). In the study evaluating metformin and alogliptin by Nauck et al a trend towards lower proinsulin: insulin ratio was observed with alogliptin. ${ }^{67}$ In summary, alogliptin, like other DPP-4 inhibitors, could theoretically preserve beta-cell function, but long-term studies will be needed to prove this to be true.

\section{Effects on lipids}

Effects on lipid parameters, evaluated across the alogliptin studies, have been minor. Changes in LDL were $-3.2 \mathrm{mg} / \mathrm{dL}$ compared with placebo and $+3.9 \mathrm{mg} / \mathrm{dL}(P=0.044)$ in monotherapy and in combination therapy with glyburide. ${ }^{65,66}$ The effects on other lipid parameters were non significant. ${ }^{65}$ In add-on therapy to metformin, there have been no significant effects on lipid profiles. ${ }^{67}$

\section{Effects on weight}

Weight changes noted when alogliptin was used in monotherapy in doses of $12.5 \mathrm{mg}$ or $25 \mathrm{mg}$ have not been clinically or statistically significant. ${ }^{65}$ Minor increases in weight were seen when alogliptin was added to the background of sulfonylurea: $-0.2 \mathrm{~kg}$ placebo, $+0.6 \mathrm{~kg}$ alogliptin $12.5 \mathrm{mg}$ $(P=0.018)$ and $+0.68 \mathrm{~kg}$ for alogliptin $25 \mathrm{mg}(P=0.010) .{ }^{66}$ 
Alogliptin proved to be weight neutral when added to metformin. Mean differences in weight relative to placebo were $0.0 \mathrm{~kg}$ and $-0.3 \mathrm{~kg}$ for $12.5 \mathrm{mg}$ and $25 \mathrm{mg}$ respectively. ${ }^{67}$ These results showing minor increases in mean weight are consistent with the results from previous studies done with other DPP-4 inhibitors, sitagliptin $(+0.7 \mathrm{~kg}, P=0.008)$ and vildagliptin $(+0.8 \mathrm{~kg}, P=0.009){ }^{70}$

A summary of the clinical efficacy of alogliptin as monotherapy and combination therapy is included in Table 1.

\section{Efficacy of alogliptin compared to other DPP-4 inhibitors}

There is much experience with the other available DPP-4 inhibitors sitagliptin and vildagliptin. However, there are no head-to-head studies reported comparing sitagliptin and vildagliptin, nor have there been studies comparing alogliptin with these currently approved DPP-4 inhibitors. Caution must therefore be exercised in judging relative efficacy. A meta-analysis comparing sitagliptin and vildagliptin with placebo showed that they resulted in significant reduction of $\mathrm{HbA}_{1 \mathrm{c}}$ values, $-0.6 \%$ with sitagliptin $(95 \% \mathrm{CI}-0.8$ to -0.4 , $P<0.00001)$ and $-0.7 \%$ with vildagliptin $(95 \% \mathrm{CI}-0.9$ to $-0.6, P<0.001){ }^{70}$ Combination therapy resulted in additional lowering of $\mathrm{HbA}_{1 \mathrm{c}}$ with both agents. However, monotherapy with either DPP-4 inhibitor proved inferior in comparison to monotherapy with either metformin or sulfonylureas. ${ }^{70}$ Saxagliptin is another DPP-4 inhibitor undergoing phase 3 trials and is also showing placebo-adjusted $\mathrm{HbA}_{1 \mathrm{c}}$ reductions of $-0.45 \%$ to $-0.63 \%$. $^{71,72}$

The improvements in $\mathrm{HbA}_{1 \mathrm{c}}$ seen with alogliptin appear to be in the same range as with the alternative DPP-4 inhibitors.

\section{Clinical safety}

Clinical safety of alogliptin has been evaluated in multiple studies with doses ranging from 6.25 to $800 \mathrm{mg}$. It has also been studied in patients with renal and hepatic impairment.

\section{Monotherapy}

\section{Single-dose study}

Covington et al studied single increasing doses of alogliptin in 36 subjects. ${ }^{54}$ Thirty received alogliptin in doses ranging from $25 \mathrm{mg}$ to $800 \mathrm{mg}$ and 6 received placebo. Asymptomatic hypoglycemia was reported in 5 subjects ( 1 on $50 \mathrm{mg}, 2$ on $200 \mathrm{mg}, 1 \mathrm{on} 400 \mathrm{mg}$ of alogliptin and 1 on placebo). Other adverse events reported in one subject each include: dizziness (100 mg), syncope (200 mg), constipation (200 mg), viral infection (400 mg), hot flush (placebo) and nausea (placebo). ${ }^{54}$

\section{Multiple-dose study}

In a multiple-dose study of 56 subjects given alogliptin in doses ranging from $25 \mathrm{mg}$ to $400 \mathrm{mg}$ for 14 days, commonly reported adverse events included headache (6/16), dizziness (4/16) and constipation in 3/16. These events occurred primarily at the highest dose of alogliptin. There were no discontinuations from the study due to side effects. ${ }^{55}$

\section{Phase 3 studies}

In a 26-week study examining 329 subjects on alogliptin monotherapy, DeFronzo et al showed an overall incidence of adverse events (AEs) of $68.4 \%$ with $12.5 \mathrm{mg}, 67.4 \%$ with $25 \mathrm{mg}$ and $70.3 \%$ with placebo. ${ }^{65}$ However, only $17.2 \%$, $23.3 \%$ and $22.7 \%$ were considered drug related in the placebo, alogliptin $12.5 \mathrm{mg}$ and $25 \mathrm{mg}$ groups, respectively. Discontinuation of therapy due to side effects occurred in similar proportions of patients across the treatment groups (1.5 to $2.3 \%)$.. Serious AEs occurred without relation to dose (12.5 mg: 3.8\%; $25 \mathrm{mg}$ : 0.8\%; placebo: 3.1\%) and were considered unrelated to the drug. Most common AEs were nasopharyngitis $(7.8 \%, 9.0 \%$ and $7.6 \%$; with placebo, $12.5 \mathrm{mg}$ and $25 \mathrm{mg}$, respectively), headache (4.7\%, 7.5\% and $6.8 \%$; with placebo, $12.5 \mathrm{mg}$ and $25 \mathrm{mg}$, respectively) and upper respiratory tract infection $(9.4 \%, 3.8 \%$ and $4.5 \%$; with placebo, $12.5 \mathrm{mg}$ and $25 \mathrm{mg}$ ). The incidence of hypoglycemia was low and similar across groups $(1.6 \%$ with placebo and $3.0 \%, 1.5 \%$ with $12.5 \mathrm{mg}$ and $25 \mathrm{mg}$ ). Hypoglycemic events were not severe and did not require assistance. Skinrelated AEs, primarily pruritus, were higher in the treated groups (12.5 mg, 3\%; $25 \mathrm{mg}, 1.5 \%$; 0 with placebo) ${ }^{65}$

Pratley et al studied 500 patients using alogliptin as add-on therapy to glyburide (66). AEs were reported in $64 \%$ of patients treated with alogliptin $12.5 \mathrm{mg}$, and $63 \%$ of patients on $25 \mathrm{mg}$ dose, compared with $54 \%$ in the placebo group. Most AEs were mild in intensity and not considered treatment-related. Serious AEs were reported in $2 \%$ of placebo-treated patients, $5.4 \%$ of patients on alogliptin $12.5 \mathrm{mg}$ and $5.6 \%$ of patients treated with the $25 \mathrm{mg}$ alogliptin dose. AEs that occurred in $\geq 5 \%$ of patients in any treatment group (including placebo) included upper respiratory infection, urinary tract infection, headache and hypertension. There was also an increased incidence of skin-related events, mainly pruritus $(0 \%$, $3 \%$ and $6 \%$ with placebo, $12.5 \mathrm{mg}$ and $25 \mathrm{mg}$ ). Gastrointestinal side effects occurred with the same frequency in the placebo and $12.5 \mathrm{mg}$ groups, with a nominally higher incidence at $25 \mathrm{mg}$. The incidence of hypoglycemia was $11.1 \%$ for placebo, 15.8 for alogliptin $12.5 \mathrm{mg}$ and $9.6 \%$ 


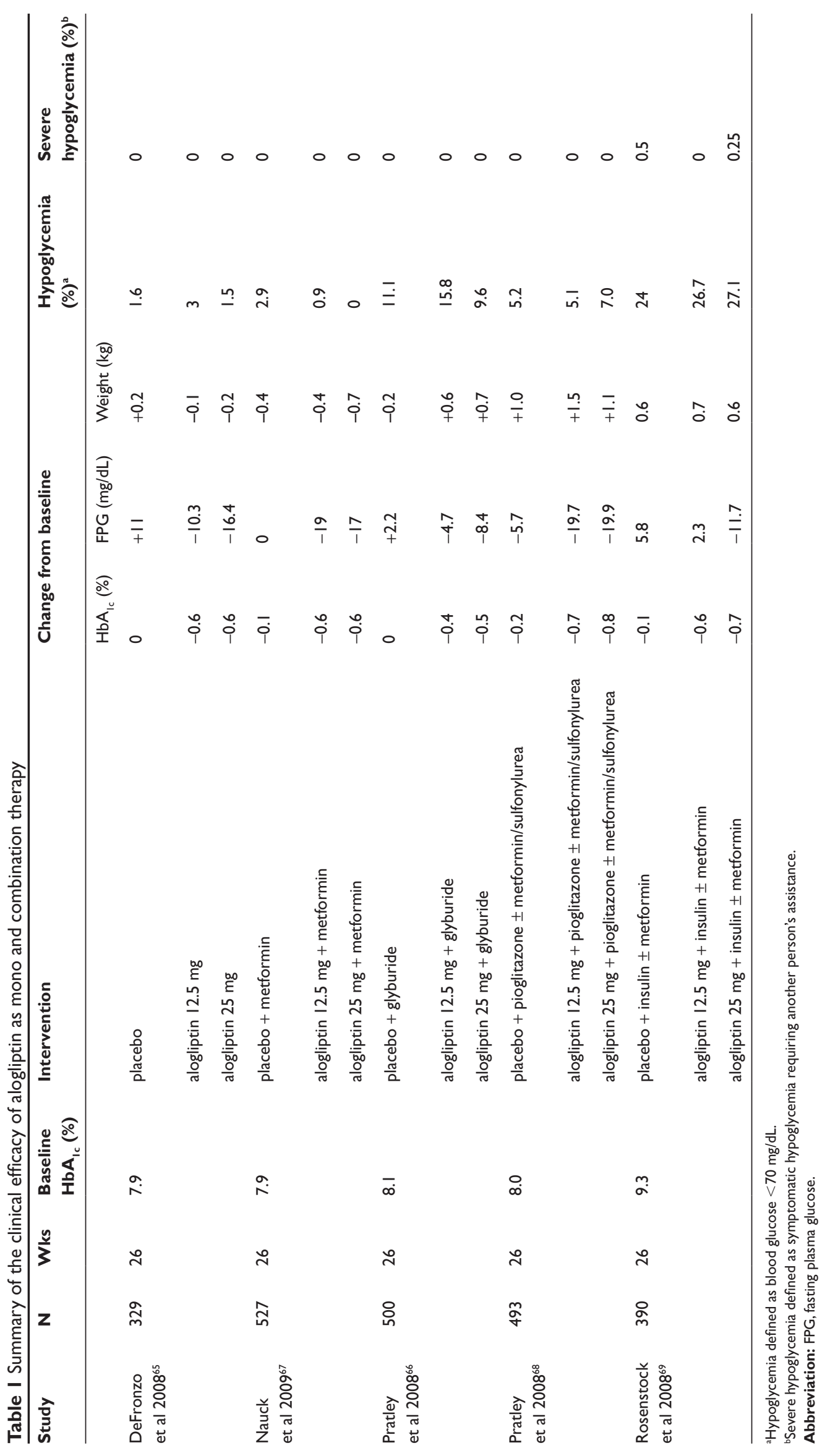


for alogliptin $25 \mathrm{mg}$. Thus, addition of alogliptin did not increase the risk of hypoglycemia attributable to glyburide therapy. ${ }^{66}$

In a study of alogliptin in combination with metformin in 201 patients, Nauck et al found that the majority of AEs were unrelated to the study drug. ${ }^{67}$ The incidence of serious AEs was similar across treatment groups $(2.8 \%$ to $3.9 \%)$. The incidence of hypoglycemia was low $(\leq 1 \%)$ across all groups and there were no severe hypoglycemic events requiring assistance. Skin-related events occurred in 7.7\% of patients in the placebo group, $12.2 \%$ in the $12.5 \mathrm{mg}$ group and $11.6 \%$ in the $25 \mathrm{mg}$ group. These included dry skin, rash, eczema and pruritus. ${ }^{67}$

In a study of alogliptin added to pioglitazone, the $\mathrm{AE}$ rates among 372 patients completing the study were: $64.9 \%$ with placebo, $69.7 \%$ with alogliptin $12.5 \mathrm{mg}$ and $72.4 \%$ with alogliptin $25 \mathrm{mg} .{ }^{68}$ The incidence of hypoglycemia was low (5.2\%, placebo; 5.1\%, $12.5 \mathrm{mg} ; 7 \%, 25 \mathrm{mg}$ ).

Alogliptin was studied as an addition to insulin therapy in 390 patients. Patients experiencing $\geq 1 \mathrm{AE}$ (73.6\%, placebo; $67.9 \%, 12.5 \mathrm{mg} ; 66.7 \%, 25 \mathrm{mg})$ and $\geq 1$ serious AE (4.7\%, placebo; $6.1 \%, 12.5 \mathrm{mg} ; 5.4 \%, 25 \mathrm{mg}$ ) were similar across treatment groups. The incidence of severe hypoglycemia was low (1.6\%, placebo; $0 \%, 12.5 \mathrm{mg} ; 0.8 \%, 25 \mathrm{mg})$ and similar across groups. ${ }^{69}$

\section{Skin toxicity}

Preclinical studies done with other DPP-4 inhibitors, vildagliptin and saxagliptin, have raised the concern of necrotic skin lesions observed in monkeys, the mechanism of which is unclear. ${ }^{73}$ However such skin lesions have not been observed in humans, or in preclinical or clinical studies with sitagliptin ${ }^{74}$ or alogliptin. The relationship of the monkey skin lesions to DPP-4 inhibition vs DPP-8/9 inhibition remains unresolved. ${ }^{75}$ Serious allergic and hypersensitivity reactions such as anaphylaxis, angioedema, and exfoliative skin conditions including StevensJohnson syndrome were reported in patients treated with sitagliptin in post-marketing reports. ${ }^{76}$ The alogliptin studies have incorporated a search for skin lesions, with a marginally higher rate than in placebo, the major finding being pruritus.

\section{Safety profile of alogliptin compared with other DPP-4 inhibitors}

Like other DPP-4 inhibitors, alogliptin is well tolerated overall. Severe hypoglycemia requiring third-party assistance has not been reported in studies done on DPP-4 inhibitors. This is not surprising, because secretion of incretins is glucosedependent. ${ }^{77}$ Meta-analysis of all the available studies on sitagliptin and vildagliptin showed a risk of gastrointestinal side effects comparable to placebo. Risk of all-cause infections (nasopharyngitis, upper respiratory infection, urinary tract infection, sinusitis) was higher with sitagliptin (odds ratio 1.34, 95\% CI 1.10 to $1.64, P=0.004$ ), but not for vidagliptin. ${ }^{70}$ Since this side effect may be related to the prolonged action of another DPP4 substrate, substance $\mathrm{P},{ }^{78}$ it is possible that the same side effects will be noted with alogliptin as well. Vildagliptin is also reported to cause pedal edema which is not reported with alogliptin. ${ }^{79,80}$ Rare cases of hepatic dysfunction and hepatitis have been reported with vildagliptin, and it is recommended to monitor liver function tests every 3 months for the first year of therapy. ${ }^{70}$ Liver enzyme abnormalities have not been observed with alogliptin thus far. It is not known whether DPP4 selectivity of alogliptin and sitagliptin, compared to vildagliptin (which inhibits both DPP-4 and DPP-8 enzymes), has clinical significance. While DPP-4 protein has a role in T-cell mediated immune response, DPP-8 and DPP-9 enzymes (located in leukocytes) are involved in T-cell activation and the processes of cell adhesion, migration and apoptosis. It has been shown ${ }^{81}$ that inhibition of DPP-8 and 9 suppresses mitogen-stimulated T-cell responses but DPP-4 selective inhibition does not. Again, the clinical significance (if any) of the DPP-4 vs DPP-8 selectivity is not clear at this point, and long-term clinical follow up data are needed. ${ }^{82}$ At this time, it is unclear whether there have been sufficient cardiac events in the alogliptin-treated populations in the research studies to date to satisfy potential cardiac safety concerns.

\section{Special populations Patients with renal and hepatic impairment}

Alogliptin $50 \mathrm{mg}$ administered to patients with renal impairment did not cause any increase in AEs. ${ }^{83}$ It was given to 6 subjects in each group of mild, moderate, severe and end stage renal disease, and $25 \%$ experienced at least one $\mathrm{AE}$, but were judged to be mild and unrelated to drug. This incidence of AEs was similar to their respective healthy age- and sexcontrolled controls. Based on this study, no dose adjustments were recommended in patients with renal insufficiency. ${ }^{83}$ Administration of $25 \mathrm{mg}$ of alogliptin to 8 subjects with moderate hepatic impairment did not result in any serious AEs. ${ }^{84}$

\section{Theoretical issues}

There are theoretical concerns ${ }^{85}$ stemming from the ubiquitous nature of DPP-4 enzyme presence: namely, this membraneassociated protein is present in many tissues including kidneys, intestine, hepatocytes, vascular endothelium, T-cells, B cells 
and natural killer cells. ${ }^{86}$ DPP-4 has two major functions: a) enzymatic action that includes cleavage of oligopeptides and b) messenger action by activation of intracellular signaling pathways. ${ }^{87}$ While DPP-4 inhibitors do not affect the signaling action, there is a concern that inhibition of enzymatic action on regulatory peptides may produce unforeseeable AEs. Enzymatic action involves cleavage of oligopeptides and regulating metabolism and activation of peptides such as YY (involved in gastrointestinal functions), neuropeptide $Y$ (involved in regulation of food intake) and brain-derived natriuretic peptide (BNP) (involved in vasodilatation, natriuresis). Clinical consequences of blockade of these peptides are not obvious at this time but warrant long-term follow up. In addition, DPP-4 protein has a role in T-cell mediated immune response. This raises concerns of possible side effects, related to reduced NK and T-cell function. ${ }^{75}$

\section{Conclusions}

Alogliptin is a new addition to incretin based therapies for type 2 diabetes. Like other agents in the DPP-4 inhibitor class, it offers good tolerability, lack of severe hypoglycemia, and weight neutrality as major advantages. In addition, thus far it appears to be safe for use in patients with co-morbidities such as heart failure and renal failure. In as much as endogenous GLP-1 has a beneficial effect on beta-cell mass, there is a hope that the DPP-4 inhibitor class might have such a benefit. That, however, has yet to be proven, not only for alogliptin but for other members of the DPP-4 class. ${ }^{85}$ On the other hand, alogliptin, like other DPP-4 inhibitors, is a new and hence costly agent of only modest efficacy. Mean $\mathrm{HbA}_{1 \mathrm{c}}$ reductions of $0.5 \%$ to $0.8 \%$ seen with alogliptin and other DPP-4 inhibitors are markedly inferior to the $1.0 \%$ to $2.0 \%$ reductions seen with metformin or sulfonylurea therapy and $1.5 \%$ to $3.5 \%$ reductions with addition of insulin therapy. The weight loss seen with GLP-1 agents does not occur with the current DPP-4 inhibitors. However, because of the low incidence of hypoglycemia and other side effects, the DPP-4 inhibitors have a place in treatment of vulnerable patients, such as the elderly.

At this time, there is a lack of long-term safety data for alogliptin and other DPP-4 inhibitors, especially those related to generalized DPP-4 inhibition. Studies of longer duration and careful postapproval surveillance are needed to assess the safety of alogliptin. Undoubtedly such studies will proceed to assess long-term cardiac events in alogliptin-treated patients. Such large-scale studies should clarify the role of alogliptin in the armamentarium of therapies we use to treat type 2 diabetes mellitus.

\section{Disclosure}

The authors disclose no conflicts of interest.

\section{References}

1. DeFronzo RA. Pathogenesis of type 2 diabetes mellitus. Med Clin North Am. 2004;88(4):787-835.

2. Wild S, Roglic G, Green A, Sicree R, King H. Global prevalence of diabetes: estimates for the year 2000 and projections for 2030. Diabetes Care. 2004;27(5):1047-1053.

3. UK prospective Diabetes Study (UKPDS) Group: Intensive blood glucose control with sulphonylureas or insulin compared with conventional treatment and risk of complication in patients with type 2 diabetes (UKPDS 33). Lancet. 1998;352(9131):837-853.

4. Saydah S, Fradkin J, Cowie C. Poor control of risk factors for vascular disease among adults with previously diagnosed diabetes. JAMA. 2004;291(3):335-42.

5. Baggio LL, Drucker DJ. Biology of incretins: GLP-1 and GIP. Gastroenterology. 2007;132(6):2131-2157.

6. Gautier JF, Fetita S, Sobngwi E, Salaün-Martin C. Biological actions of the incretins GIP and GLP-1 and therapeutic perspectives in patients with type 2 diabetes. Diabetes Metab. 2005;31(3 Pt 1):233-42.

7. Drucker DJ. The biology of incretin hormones. Cell Metab. 2006; 3(3):153-165.

8. Yip RG, Wolfe MM. GIP biology and fat metabolism. Life Sci. 2000;66(2):91-103.

9. Trümper A, Trümper K, Hörsch D. Mechanisms of mitogenic and antiapoptotic signaling by glucose-dependent insulinotropic polypeptide in beta (INS-1) cells. J Endocrinol. 2002;174(2):233-246.

10. Trümper A, Trümper K, Trusheim H, Arnold R, Göke B, Hörsch D. Glucosedependent insulinotropic polypeptide is a growth factor for beta (INS-1) cells by pleiotropic signaling. Mol Endocrinol. 2001;15(9):1559-1570.

11. Ross SA, Brown JC, Dupré J. Hypersecretion of gastric inhibitory polypeptide following oral glucose in diabetes mellitus. Diabetes. 1977;26(6):525-529.

12. Vilsbøll T, Krarup T, Deacon CF, Madsbad S, Holst JJ. Reduced postprandial concentrations of intact biologically active glucagon-like peptide 1 in type 2 diabetic patients. Diabetes. 2001;50(3):609-613.

13. Lynn FC, Pamir N, Ng EH, McIntosh CH, Kieffer TJ, Pederson RA. Defective glucose-dependent insulinotropic polypeptide receptor expression in diabetic fatty Zucker rats. Diabetes. 2001;50(5):1004-1011.

14. Zhou J, Livak MF, Bernier M, et al. Ubiquitination is involved in glucose-mediated downregulation of GIP receptors in islets. Am J Physiol Endocrinol Metab. 2007;293(2):E538-547.

15. Pratley R. Islet dysfunction: An underlying defect in the pathophysiology of type 2 diabetes. Endocrinol Metab Clin North Am. 2006; 35 Suppl 1:6-11.

16. Kim W, Egan JM. The role of incretins in glucose homeostasis and diabetes treatment. Pharmacol Rev. 2008;60(4):470-512.

17. Toft-Nielsen MB, Damholt MB, Madsbad S, et al. Determinants of the impaired secretion of glucagon-like peptide-1 in type 2 diabetic patients. J Clin Endocrinol Metab. 2001;86(8):3717-3723.

18. Nauck M, Stöckmann F, Ebert R, Creutzfeldt W. Reduced incretin effect in type 2 (non-insulin-dependent) diabetes. Diabetologia. 1986;29(1):46-52.

19. Vollmer K, Gardiwal H, Menge BA, et al. Hyperglycemia acutely lowers the postprandial excursions of glucagon-like Peptide-1 and gastric inhibitory polypeptide in humans. J Clin Endocrinol Metab. 2009; 94(4):1379-1385.

20. Vollmer K, Holst JJ, Baller B, Ellrichmann M, Nauck MA, Schmidt WE, Meier JJ. Predictors of incretin concentrations in subjects with normal, impaired, and diabetic glucose tolerance. Diabetes. 2008;57(3):678-687.

21. Nauck MA, Heimesaat MM, Orskov C, Holst JJ, Ebert R, Creutzfeldt W. Preserved incretin activity of glucagon-like peptide 1 [7-36 amide] but not of synthetic human gastric inhibitory polypeptide in patients with type-2 diabetes mellitus. J Clin Invest. 1993;91(1):301-307. 
22. Little TJ, Pilichiewicz AN, Russo A, et al. Effects of intravenous glucagon-like peptide-1 on gastric emptying and intragastric distribution in healthy subjects: relationships with postprandial glycemic and insulinemic responses. J Clin Endocrinol Metab. 2006;91(5):1916-1923.

23. Dupre J. Glycaemic effects of incretins in Type 1 diabetes mellitus: a concise review, with emphasis on studies in humans. Regul Pept. 2005;128(2):149-157.

24. Zander M, Christiansen A, Madsbad S, Holst JJ. Additive effects of glucagon-like peptide 1 and pioglitazone in patients with type 2 diabetes. Diabetes Care. 2004;27(8):1910-1914.

25. Degn KB, Juhl CB, Sturis J, et al. One week's treatment with the long-acting glucagon-like peptide 1 derivative liraglutide (NN2211) markedly improves 24-h glycemia and alpha- and beta-cell function and reduces endogenous glucose release in patients with type 2 diabetes Diabetes. 2004;53(5):1187-1194.

26. Meneilly GS, Greig N, Tildesley H, Habener JF, Egan JM, Elahi D. Effects of 3 months of continuous subcutaneous administration of glucagon-like peptide 1 in elderly patients with type 2 diabetes. Diabetes Care. 2003;26(10):2835-2841.

27. Nyström T, Gutniak MK, Zhang Q, et al. Effects of glucagon-like peptide- 1 on endothelial function in type 2 diabetes patients with stable coronary artery disease. Am J Physiol Endocrinol Metab. 2004;287(6): E1209-1215.

28. Fineman MS, Bicsak TA, Shen LZ, et al. Effect on glycemic control of exenatide (synthetic exendin-4) additive to existing metformin and/or sulfonylurea treatment in patients with type 2 diabetes. Diabetes Care. 2003;26(8):2370-2377.

29. Moretto T, Milton D, Ridge T, et al. Efficacy and tolerability of exenatide monotherapy over 24 weeks in antidiabetic drug-naive patients with type 2 diabetes: a randomized, double-blind, placebo-controlled, parallel-group study. Clin Ther. 2008;30(8):1448-1460.

30. Zinman B, Hoogwerf B, Durán García S, et al. The effect of adding exenatide to a thiazolidinedione in suboptimally controlled type 2 diabetes: a randomized trial. Ann Intern Med. 2007;146(7):477-485.

31. DeFronzo R, Ratner R, Han J, Kim D, Fineman M, Baron A. Effects of exenatide (exendin-4) on glycemic control and weight over 30 weeks in metformin-treated patients with type 2 diabetes. Diabetes Care. 2005;28(5):1092-1100.

32. Buse JB, Henry RR, Han J, Kim DD, Fineman MS, Baron AD; Exenatide-113 Clinical Study Group. Effects of exenatide (exendin-4) on glycemic control over 30 weeks in sulfonylurea-treated patients with type 2 diabetes. Diabetes Care. 2004;27(11):2628-2635.

33. Dupré J, Behme MT, McDonald TJ. Exendin-4 normalized postcibal glycemic excursions in type 1 diabetes. J Clin Endocrinol Metab. 2004;89(7):3469-3473.

34. Ahrén B, Schmitz O. GLP-1 receptor agonists and DPP-4 inhibitors in the treatment of type 2 diabetes. Horm Metab Res. 2004;36(11-12) 867-876.

35. Mest HJ, Mentlein R. Dipeptidyl peptidase inhibitors as new drugs for the treatment of type 2 diabetes. Diabetologia. 2005;48(4):616-620.

36. Amori RE, Lau J, Pittas AG. Efficacy and safety of incretin therapy in type 2 diabetes: systematic review and meta-analysis. JAMA. 2007;298(2):194-206.

37. Lyseng-Williamson KA. Sitagliptin. Drugs. 2007;67(4):587-597.

38. Raz I, Hanefeld M, Xu L, Caria C, Williams-Herman D, Khatami H; Sitagliptin Study 023 Group. Efficacy and safety of the dipeptidyl peptidase-4 inhibitor sitagliptin as monotherapy in patients with type 2 diabetes mellitus. Diabetologia. 2006;49(11):2564-2571.

39. Zerilli T, Pyon EY. Sitagliptin phosphate: a DPP-4 inhibitor for the treatment of type 2 diabetes mellitus. Clin Ther. 2007;29(12):2614-2634.

40. Williams-Herman D, Johnson J, Teng R. et al. Efficacy and safety of initial combination therapy with sitagliptin and metformin in patients with type 2 diabetes: a 54-week study. Curr Med Res Opin. 2009;25(3):569-583.

41. Raz I, Chen Y, Wu M, et al. Efficacy and safety of sitagliptin added to ongoing metformin therapy in patients with type 2 diabetes. Curr Med Res Opin. 2008;24(2):537-550.
42. Scott R, Loeys T, Davies MJ, Engel SS; Sitagliptin Study 801 Group. Efficacy and safety of sitagliptin when added to ongoing metformin therapy in patients with type 2 diabetes. Diabetes Obes Metab. 2008;10(10):959-969.

43. Karasik A, Aschner P, Katzeff H, Davies MJ, Stein PP. Sitagliptin, a DPP-4 inhibitor for the treatment of patients with type 2 diabetes: a review of recent clinical trials. Curr Med Res Opin. 2008;24(2):489-496.

44. Croxtall JD, Keam SJ. Vildagliptin: a review of its use in the management of type 2 diabetes mellitus. Drugs. 2008;68(16):2387-2409.

45. Dejager S, Razac S, Foley JE, Schweizer A. Vildagliptin in drugnaïve patients with type 2 diabetes: a 24-week, double-blind, randomized, placebo-controlled, multiple-dose study. Horm Metab Res. 2007;39(3):218-223.

46. Bosi E, Dotta F, Jia Y, Goodman M. Vildagliptin plus metformin combination therapy provides superior glycaemic control to individual monotherapy in treatment-naive patients with type 2 diabetes mellitus. Diabetes Obes Metab. 2009 Mar 23. [Epub ahead of print].

47. Göke B, Hershon K, Kerr D, et al. Efficacy and safety of vildagliptin monotherapy during 2-year treatment of drug-naïve patients with type 2 diabetes: comparison with metformin. Horm Metab Res. 2008;40(12):892-895.

48. Ferrannini E, Fonseca V, Zinman B, et al. Fifty-two-week efficacy and safety of vildagliptin vs glimepiride in patients with type 2 diabetes mellitus inadequately controlled on metformin monotherapy. Diabetes Obes Metab. 2009;11(2):157-166.

49. DeFronzo RA, Okerson T, Viswanathan P, Guan X, Holcombe JH, MacConell L. Effects of exenatide versus sitagliptin on postprandial glucose, insulin and glucagon secretion, gastric emptying, and caloric intake: a randomized, cross-over study. Curr Med Res Opin. 2008;24(10):2943-2952.

50. Madsbad S, Krarup T, Deacon CF, Holst JJ. Glucagon-like peptide receptor agonists and dipeptidyl peptidase-4 inhibitors in the treatment of diabetes: a review of clinical trials. Curr Opin Clin Nutr Metab Care. 2008;11(4):491-499.

51. Feng J, Zhang Z, Wallace MB, et al. Discovery of alogliptin: A potent, selective, bioavailable, and efficacious inhibitor of dipeptidyl peptidase IV. J Med Chem. 2007;50:2297-2300.

52. Christopher R, Davenport M, Gwaltney S, et al. Pharmacokinetic and pharmacodynamic profiles of SYR-322, a novel inhibitor of dipeptidyl peptidase-4, in rats, dogs, and monkeys [abstract]. Diabetes. 2006; 55 Suppl 1:A107-A108.

53. Karim A, Bridson W, Fleck P, et al. Disposition of the dipeptidyl peptidase-4 inhibitor[14C] alogliptin benzoate ([14C]SYR-322) after oral administration to healthy male subjects [abstract]. AAPS J. 2007;9(S2):T3552.

54. Covington $\mathrm{P}$, Christopher R, Davenport M, et al. Pharmacokinetics, pharmacodynamics, and tolerability of single increasing doses of the dipeptidyl peptidase- 4 inhibitor alogliptin in healthy male subjects. Clin Ther. 2008;30(3):513-527.

55. Covington P, Christopher R, Davenport M, et al. Pharmacokinetic, pharmacodynamic, and tolerability profiles of the dipeptidyl peptidase- 4 inhibitor alogliptin: A randomized, double- blind, placebo-controlled, multiple-dose study in adult patients with type 2 diabetes. Clin Ther. 2008;30(3):499-512.

56. Covington P,Christopher R,Davenport M, et al. Lack of pharmacokinetic interaction between alogliptin benzoate (SYR-322) and metformin in healthy subjects [abstract]. Diabetes. 2007;56(suppl 1): A541-A542.

57. Fleck P, Karim A, Harris S, et al. Lack of effect of multiple doses of alogliptin benzoate (SYR-322) on the pharmacokinetics of glyburide in healthy subjects [abstract]. Diabetes. 2007;56(suppl 1):A?

58. Karim A, Fleck P, Joseph M, et al. No pharmacokinetic interaction between alogliptin benzoate (SYR-322) and pioglitazone hydrochloride [abstract]. Diabetes. 2007;56 Suppl 1:A536.

59. Karim A, Harris S, Fleck P, Moore Schuster J, Zhang W, Mekki Q. Effect of fluconazole, ketoconazole, and gemfibrozil on the pharmacokinetics of alogliptin benzoate (SYR-322) in healthy subjects [abstract 105] J Clin Pharmacol. 2007;47(9):1207. 
60. Karim A, Harris S, Fleck P, Moore R, Zhang W, Mekki Q. Assessment of drug interaction between alogliptin benzoate (SYR-322), a highly selective dipeptidyl peptidase-4 inhibitor, and warfarin at steady state [abstract 106]. J Clin Pharmacol. 2007;47(9):1207.

61. Karim A, Chiselko P, Fleck P, Harris S, Munsaka M, Mekki Q. Lack of effect of cyclosporine on the single dose pharmacokinetics of alogliptin, a novel dipeptidyl peptidase-4 inhibitor, in healthy male subjects [abstract]. Clin Pharmacol Ther. 2008;83 Suppl 1:S13.

62. Karim A, Copa A, Fleck P, Helland J, Munsaka M, Mekki Q. Effects of alogliptin on the pharmacokinetics and pharmacodynamics of norethindrone and ethinyl estradiol (ORTHO-NOVUM(R) 1/35) in healthy adult female subjects [abstract]. Clin Pharmacol Ther. 2008;83 Suppl:S13.

63. Karim A, Fleck P, Harris S, Munsaka M, Weiss M, Mekki Q. Lack of pharmacokinetic interaction between alogliptin, a highly selective dipeptidyl peptidase-4 inhibitor, and atorvastatin in healthy subjects [abstract]. Clin Pharmacol Ther. 2008;83 Suppl 1:S14.

64. Karim A, Fleck P, Harris S, Weiss M, Zhang W, Mekki Q. Lack of pharmacokinetic interaction between multiple doses of the dipeptidyl peptidase-4 inhibitor alogliptin and digoxin in healthy subjects [abstract]. Clin Pharmacol Ther. 2008;83 Suppl 1:S12-S13.

65. DeFronzo R, Fleck P, Wilson C, Mekki Q; Alogliptin Study 010 Group. Efficacy and safety of the dipeptidyl peptidase-4 inhibitor alogliptin in patients with type 2 diabetes and inadequate glycemic control: a randomized, double-blind, placebo-controlled study. Diabetes Care. 2008;31:2315-2317.

66. Pratley R, Kipnes M, Fleck P, Wilson C, Mekki Q; Alogliptin Study 007 Group. Efficacy and safety of the dipeptidyl peptidase-4 inhibitor alogliptin in patients with type 2 diabetes inadequately controlled by glyburide monotherapy. Diabetes Obes Metab. 2009;11(2):167-176.

67. Nauck M, Ellis G, Fleck P, Wilson C, Mekki Q; Alogliptin Study 008 Group. Efficacy and safety of adding the dipeptidyl peptidase-4 inhibitor alogliptin to metformin therapy in patients with type 2 diabetes inadequately controlled with metformin monotherapy: a multicentre, randomised, double-blind, placebo-controlled study. Int J Clin Pract. 2009;63(1):46-55.

68. Pratley R, Reusch J, Fleck P, Wilson C, Mekki Q. Alogliptin added to pioglitazone therapy improves glycemic control in patients with type 2 diabetes without increasing weight gain or hypoglycemia [abstract]. Diabetologia. 2008;51 Suppl 1:S343.

69. Rendell M, Rosenstock J, Gross J, Fleck P, Wilson C, Mekki Q. Addition of Alogliptin to insulin therapy reduces $\mathrm{HbAlc}$ without increasing weight gain or hypoglycemia in patients with type 2 diabetes [abstract]. Diabetologia. 2008;51 Suppl 1:S37.

70. Richter B, Bandeira-Echtler E, Bergerhoff K, Lerch C. Emerging role of dipeptidyl peptidase- 4 inhibitors in the management of type 2 diabetes. Vasc Health Risk Manag. 2008;4(4):753-768.

71. Rosenstock J, Sankoh S, List JF. Glucose-lowering activity of the dipeptidyl peptidase-4 inhibitor saxagliptin in drug-naive patients with type 2 diabetes. Diabetes Obes Metab. 2008;10(5):376-386.

72. DeFronzo RA, Hissa MN, Garber AJ, et al; for the Saxagliptin 014 Study Group. The Efficacy and safety of Saxagliptin when added to Metformin therapy in patients with inadequately controlled Type 2 diabetes on Metformin alone. Diabetes Care. 2009 Jun 23. [Epub ahead of print].
73. Emea.europa.edu [homepage on the internet]. Summary of product characteristics of vildagliptin. http://www.emea.europa.eu/humandocs/ PDFs/ EPAR/galvus/H-771-PI-en.pdf. Accessed June 26, 2009.

74. Merck shares Januvia safety data following FDA decision to delay approval of rival drug. Internal medicine world report; issue December 2006. http://www.imwr.com/issues/articles/2006-12_45.asp. Accessed June 26, 2009.

75. Emea.europa.edu [homepage on the internet]. Scientific discussion on vildagliptin: pharmacodynamics, pharmacokinetics, efficacy and safety. www.emea.europa.eu/humandocs/PDFs/EPAR/eucreas/H-807-en6.pdf. Accessed June 26, 2009.

76. Fda.gov/medwatch[homepage on the internet]. Patient information Januvia; Oct 2007. www.fda.gov/medwatch/safety/2007/Oct_PI/ Januvia_PI.pdf. Accessed June 26, 2009.

77. Drucker DJ, Nauck MA. The incretin system: glucagon-like peptide-1 receptor agonists and dipeptidyl peptidase-4 inhibitors in type 2 diabetes. Lancet. 2006;368(9548):1696- 1705.

78. Lambeir AM, Scharpé S, De Meester I. DPP4 inhibitors for diabetes - what next? Biochem Pharmacol. 2008;76(12):1637-1643.

79. Rosenstock J, Baron MA, Dejager S, Mills D, Schweizer A. Comparison of vildagliptin and rosiglitazone monotherapy in patients with type 2 diabetes: a 24-week, double-blind, randomized trial. Diabetes Care. 2007;30(2):217-223.

80. Bolli G, Dotta F, Rochotte E, Cohen SE. Efficacy and tolerability of vildagliptin vs pioglitazone when added to metformin: a 24-week, randomized, double-blind study. Diabetes Obes Metab. 2008;10(1): 82-90.

81. Reinhold D, Goihl A, Wrenger S et al. Role of dipeptidyl peptidase IV (DPP IV)-like enzymes in T lymphocyte activation: investigations in DPP IV/CD26-knockout mice.Clin Chem Lab Med. 2009 Feb 10. [Epub ahead of print].

82. Burkey BF, Hoffmann PK, Hassiepen U, Trappe J, Juedes M, Foley JE. Adverse effects of dipeptidyl peptidases 8 and 9 inhibition in rodents revisited. Diabetes Obes Metab. 2008;10(11):1057-1061.

83. Karim A, fleck P, Hetman L, Marbury T, Ravis W, Cannon C, et al. Single dose pharmacokinetics of dipeptidyl peptidase-4 inhibitor alogliptin in subjects with renal impairment [poster 538 P]. Diabetes. 2008;57 Suppl 1:A160.

84. Karim A, fleck P, Dorsey D, Zhang W, Mekki Q, Preston RA. Single dose pharmacokinetics of alogliptin benzoate(SYR-322) in subjects with moderate hepatic impairment [abstract 107]. J Clin Pharmacol. 2007;47(9):1207.

85. Nathan DM. Finding new treatments for diabetes - how many, how fast... how good? N Engl J Med. 2007;356(5):437-440.

86. Lambeir AM, Durinx C, Scharpé S, De Meester I. Dipeptidyl-peptidase IV from bench to bedside: an update on structural properties, functions, and clinical aspects of the enzyme DPP IV. Crit Rev Clin Lab Sci. 2003;40(3):209-294

87. Chia CW Egan JM. Incretin-based therapies in type 2 diabetes mellitus. J Clin Endocrinol Metab. 2008;93(10):3703-3716.

Diabetes, Metabolic Syndrome and Obesity: Targets and Therapy

Dovepress

\section{Publish your work in this journal}

Diabetes, Metabolic Syndrome and Obesity: Targets and Therapy is an international, peer-reviewed open-access journal committed to the rapid publication of the latest laboratory and clinical findings in the fields of diabetes, metabolic syndrome and obesity research. Original research, review, case reports, hypothesis formation, expert opinion and commentaries are all considered for publication. The manuscript management system is completely online and includes a very quick and fair peer-review system, which is all easy to use. Visit http://www.dovepress.com/testimonials.php to read real quotes from published authors. 